\title{
IDENTITAS DAN KEARIFAN LOKAL “ISLAM SAMIN" DI ERA GLOBAL
}

\author{
Oleb: Ismail Yabya*
}

\section{Abstract}

This research aims firstly; to describe the construct of identity and local wisdom of Samin community in Kemantren village, Kedungtuban, Blora, Central Java, secondly; to explain change and continuity of their identity and local wisdom facing globalization. This research is descriptive qualitative, synthesis of library and field research. Library research studies the teaching and bistory of Saminism in general. Field research digs their identity and local wisdom through observation and unstructured interview. Informants were chosen purposively. The research was conducted on June-August 2007. The results are firstly; the construct of identity of Saminism comprises the identity of historicity, dress, language, house, marriage, and in agriculture. Their local wisdom was seen in personal attitude, social harmony attitude, and attitude towards nature. Secondly; there are factors and actors involving in change of their identity and local wisdom. There are external and internal factors, structural and cultural actors. The continuity of their identity and local wisdom goes through internalization, limitation of education, self sufficiency, and endogamy.

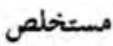

مَدف هذه الدراسة إلى إعادة تركيب الصورة الكلية للهوية والثقافة المحليين لبحتمعات "سمين" في قرية

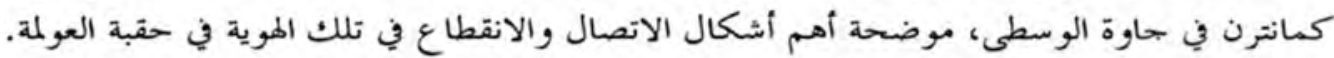

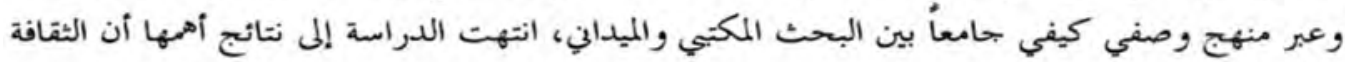

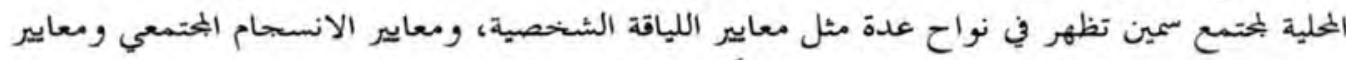

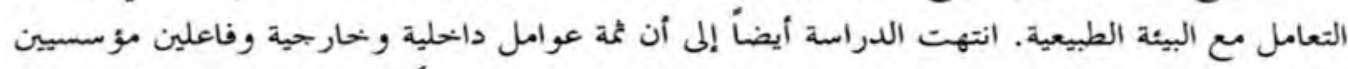

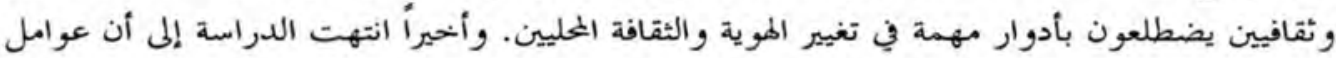

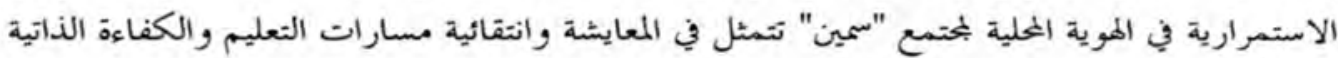
وأخيراً التزاو ج من داخل في الخونة نفس العشيرة.

Keywords: Identitas, Kearifan Lokal, Perubahan, Kesinambungan, dan Saminisme

Ketua Jurusan STAIN Surakarta. Email: ismail_yh@yahoo.com 


\section{A. Pendahuluan}

Pergaulan global sudah tidak dapat lagi dihindari oleh seseorang, kecuali seseorang itu dengan sengaja mengungkung diri dengan menjauhi interaksi dan komunikasi dengan pihak lain. ${ }^{1}$ Globalisasi (Inggris: globalization, Belanda: globalisatie atau globalisering, Prancis: mondialisation, Arab: 'awlamah) meniscayakan saling ketergantungan yang kuat (strong interdependence) antara bagian-bagian dunia. ${ }^{2}$ Perkembangan di bidang transportasi, informasi dan komunikasi membuktikan bahwa apa yang disebut dengan globalisasi itu memang sudah, sedang, dan akan terus berlangsung. Peningkatan jumlah wisatawan, mobilitas migrasi dan pekerjaan merupakan perkembangan lain yang mengikuti proses globalisasi. Kemajuan di bidang informasi dan komunikasi bahkan sudah masuk ke ruang-ruang domestik dan privasi manusia, baik dalam masyarakat modern maupun masyarakat pra-modern, seperti masyarakat Samin.

Masyarakat Samin, dengan tradisi dan pandangan dunia mereka yang unik, juga tidak bisa terlepas dari "gelombang" modernisasi dan globalisasi. Secara umum, kehidupan mereka masih sangat alami. Padahal, sebenarnya tempat tinggal mereka tidak terlalu jauh dari ranah kehidupan modern. Namun, ajaran hidup yang terus dianut membuat mereka tidak cukup mudah mengadaptasi diri dengan kehidupan modern. Sekalipun masyarakat Samin berusaha mempertahankan tradisi namun tidak urung pengaruh kemajuan zaman juga mempengaruhi mereka. Secara sangat pelan, sebagian mereka mulai memanfaatkan produk-produk dunia modern. Misalnya pemakaian traktor dan pupuk kimiawi dalam pertanian, alat-alat rumah tangga dari plastik, aluminium.

Di tengah kemajuan teknologi saat ini, sebagian pemuda Samin mulai mau mengendarai sepeda motor. Dahulu dalam bidang ekonomi, warga Samin hanya mengenal sistem barter untuk menjalankan roda perekonomian maupun pemenuhan kehidupan sehari-hari. Saat ini mereka sudah mulai menjual padi maupun palawija yang dipanen dari sawah dan ladang. Kemudian, uang yang diperoleh dari hasil penjualan itu mereka gunakan untuk membeli motor, televisi, bahkan telepon seluler. ${ }^{3}$

1 A. Qodri Azizy, Melawan Globalisasi, (Yogyakarta: Pustaka Pelajar, 2003), hal. 22.

2 Johan Meuleman (ed), "Introduction" dalam Islam in the Era of Globalization: Muslim Attitudes Towards Modernity and Identity, (Jakarta: INIS, 2001), hal. 2.

3 http://www.republika.co.id/koran_detail.asp?id=290290\&kat_id=3, dan http:// id.wikipedia.org/wiki/Ajaran_Samin/accessed 20 Mei 2007. 
Penelitian tentang konstruksi identitas dan kearifan lokal masyarakat Samin, serta bagaimana perubahan dan kesinambungan (change dan continuity) akan identitas dan kearifan lokal mereka di era modern dan global ini, menjadi alasan utama penelitian ini dilakukan. Oleh karena itu, masalah penelitian yang dapat diajukan yaitu bagaimana bentuk konstruksi identitas dan kearifan lokal masyarakat Samin? bagaimana perubahan dan kesinambungan yang terjadi dengan identitas dan kearifan lokal masyarakat Samin ketika berhadapan dengan modernisasi dan globalisasi? Faktor dan aktor apa saja yang terlibat dalam proses perubahan tersebut? Upaya apa saja yang dilakukan dalam menjaga kesinambungan identitas dan kearifan lokal Saminisme tersebut?

\section{B. Metode Penelitian}

Penelitian ini merupakan penelitian deskriptif kualitatif. Dalam melakukan penelitian ini, dari segi metode menggunakan sintesis antara penelitian kepustakaan dan penelitian lapangan. Penelitian kepustakaan (library research) dengan memanfaatkan buku-buku, hasil-hasil penelitian, dan internet digunakan untuk menelaah hal-hal yang berkaitan dengan sistem keyakinan, ajaran, sejarah, dan tradisi masyarakat Samin. Penelitian lapangan (field research) melakukan kajian empirik mengenai identitas dan kearifan lokal masyarakat Samin. Ini dilakukan dengan penelusuran informasi, pengamatan dan pemilihan informasi kunci (key informan) yang dilakukan secara purpossive. Seperti penelitian kualitatif pada umumnya, maka instrumen pengumpulan data yang digunakan meliputi observasi (pengamatan), wawancara tidak tersutruktur tetapi mendalam (in-depth interview), dan dokumentasi.

Penelitian dilakukan di Desa Kemantren, Kecamatan Kedungtuban, Kabupaten Blora, Propinsi Jawa Tengah. Meskipun orang Samin tersebar ke berbagai daerah di luar daerah asal pertama kali muncul, yaitu Blora, seperti ke Bojonegoro, Pati, Rembang, Kudus, dan Madiun, namun penelitian ini cenderung menjadikan Kabupaten Blora sebagai lokasi penelitian, sebagai daerah asal usul munculnya Saminisme.

\section{Latar Sosial Masyarakat Samin}

Kesan pertama ketika sampai di lokasi adalah sebuah potret kesederhanaan Desa Kemantren yang jauh dari hingar bingarnya kota. Beberapa rumah penduduk 
berbahan kayu dan papan, berlantai tanah, umumnya rumah di pedesaan, walaupun tidak sedikit juga yang terbuat dari batu bata dan semen. Tipe rumah penduduk rata-rata besar dengan bangunan model adat Jawa pesisiran bukan rumah joglo yakni model pagasan dan bekuk tulang. Tiap penduduk rata-rata memiliki dua rumah yaitu rumah utama dan pawon (dapur) dan kamar mandi yang terpisah dari rumah induk. Jalanan desa cukup rapi walaupun banyak yang belum diaspal.

Teknologi di bidang informasi dan transportasi seperti televisi, radio, handphone, sepeda motor, dan mobil sudah lama dinikmati masyarakat Desa Kemantren. Berada pada ketinggian tanah $42 \mathrm{~m}$ dari permukaan laut dengan suhu udara rata-rata 23-24 ${ }^{\circ} \mathrm{C}$, suhu di Desa Kemantren terasa panas terlebih di musim kemarau. Kebutuhan air bersih dapat diatasi penduduk dengan memasang sumur bor di rumah masing-masing.

Agama merupakan bagian yang tidak terpisahkan dari kehidupan masyarakat Indonesia pada umumnya. Mayoritas penduduk Desa Kemantren beragama Islam mencapai 99,9\% -walaupun dengan tingkat intensitas keIslaman yang bervariasidan hanya $0,1 \%$ beragama Kristen. Sebagian masyarakatnya -yaitu orang Saminmenganut aliran kepercayaan yang mereka sebut dengan 'laku sikep,' sedang agama mereka tetap Islam. ${ }^{4} \mathrm{Hal}$ senada diungkapkan oleh aparat Desa Kemantren, bahwa pengikut ajaran Samin terdaftar sebagai pemeluk agama Islam, meskipun mereka tidak menjalankan syariat Islam seperti shalat dan puasa. ${ }^{5}$

Namun proses "Islamisasi" (mengIslamkan orang Islam) atau lebih tepatnya "santrinisasi" terus berlangsung yang secara struktural telah dimulai sejak tahun 1989 pada masa kepemimpinan Lurah Syuhud. ${ }^{6}$ Terlahir dari keluarga santri, pada masa kepemimpinannya masyarakat Samin bersedia mencatatkan perkawinan mereka ke Kantor Urusan Agama (KUA). Tahun 1995 sebanyak 65 orang warga Samin bersedia mengikuti nikah masal yang diselenggarakan pihak pemerintah Desa ketika itu. Aktivitas keagamaan seperti pengajian dan shalat Jumat dilakukan oleh masyarakat. Rumah ibadah berupa masjid dan mushalla berdiri di sekitar tempat tinggal masyarakat Desa Kemantren. Sekolah Diniyah dan Pondok Pesantren juga beroperasi dengan baik.

Desa Kemantren mayoritas penduduknya bertani, umumnya mempunyai etos kerja yang tinggi. Dari sisi bidang pertanian Desa Kemantren dapat dikatakan maju, hal ini dapat dilihat dari jumlah fasilitas pengairan dan hasil pertanian, perkebunan

4 Wawancara dengan Bapak Nyamu 6 Juli 2007.

5 Wawancara dengan Bapak Ahmad (bukan nama sebenarnya), 6 Juli 2007.

6 Bukan nama sebenarnya. 
maupun peternakan. Tingkat ekonomi masyarakat Desa Kemantren tergolong sejahtera, karena pertanian yang maju, dengan tiga kali panen, dengan rincian dua kali panen padi dan satu kali panen palawija meliputi kacang tanah, cabe, dan bawang.

Sebagai masyarakat pedesaan, secara kebudayaan Desa Kemantren masih tergolong masyarakat paguyuban, kerukunan bersama dan gotong-royong masih kental di masyarakat. Paguyuban adalah bentuk kehidupan bersama dimana anggotaanggotanya diikat oleh hubungan batin yang murni dan bersifat alamiah dan bersifat kekal. Dasar hubungan tersebut adalah rasa cinta dan rasa kesatuan batin yang memang telah dikodratkan.

Kebudayaan di Desa Kemantren ini juga tidak terlepas dari adanya akulturasi antara kebudayaan Jawa, Islam, dan ajaran Saminisme. Hal ini dapat di lihat dari tradisi kematian dan upacara perkawinan. Sedangkan kebudayaan masyarakat Samin secara umum sama dengan masyarakat Desa Kemantren meskipun ada yang khusus yaitu dalam hal bahasa, tata cara perkawinan dan kematian.

Dalam hal seni budaya ada dua aliran di Desa Kemantren yaitu seni yang bersendikan agama seperti kasidah dan hadrah, dan seni kerakyatan seperti wayang kulit, ketoprak, tayub dan lain-lain. Kedua model kesenian ini dapat diamati ketika upacara perkawinan dan khitanan dimana untuk meramaikan acara, biasanya mereka mengundang kelompok seni tersebut. Bahkan kadang dalam satu acara kadua seni tersebut bergabung menjadi satu meskipun lain waktunya.

\section{Konstruksi Identitas dan Kearifan Lokal Masyarakat Samin}

\section{Masyarakat Samin di Desa Kemantren}

Saminisme di Desa Kemantren khususnya di Dukuh Tanduran dibawa oleh Surohidin bersama istrinya yang bernama Samsiyah (anak perempuan Ki Samin Surontiko). Surohidin adalah murid sekaligus menantu dari Samin Surontiko yang giat dan gigih menyebarkan ajaran Samin ke berbagai daerah. Di samping kedua orang tersebut, Saminisme juga dibawa oleh anak-anaknya yang lain yaitu Karto Kemis, anak pertama Ki Samin, Radimah dan Sabi'ah, yang kesemuanya tinggal di Dukuh Tanduran Desa Kemantren, Kecamatan Kedungtuban, Kabupaten Blora. ${ }^{7}$

Wawancara dengan Bapak Nyamu dan Bapak Dirto tanggal 6 dan 7 Juli 2007, lihat juga Siti Kasiyati, Perkawinan Adat Masyarakat Samin Dalam Konteks Pelaksanaan Undang—undang Perkawinan di Indonesia (UU Nomor 1 Tabun 1974): Studi Kasus di Desa Kemantren Kecamatan Kedungtuban, Kabupaten Blora (Surakarta: Skripsi STAIN Surakarta, 1997), hal. 34. 
Dari perkawinan anak-anak Ki Samin tersebut, di Desa Kemantren semakin menumbuhsuburkan ajaran Samin Surontiko, banyak masyarakat yang mengikutinya. Ketika penangkapan tokoh-tokoh Samin oleh Belanda, banyak tokoh dari desa ini yang tertangkap dan kemudian dibuang sehingga keturunannya tidak mengetahui nasib para pendahulunya.

Aliran Samin yang ada di desa ini dikenal dengan Samin Lugu yaitu ajaran Samin asli, belum ada ajaran lain yang ditambahkan. Sebagaimana dituturkan Bapak Nyamu dan Mbah Padi, menurut mereka sepeninggal Ki Samin Surontiko, Saminisme terpecah menjadi beberapa aliran, yakni Samin Lugu dan Samin Sangkak. Hasil penelitan Suhernowo seperti disebutkan oleh RPA. Soerjanto Sastroatmodjo sejak ditinggal Ki Samin, Saminisme terpecah menjadi empat varian Samin Lugu, Samin Sangkak, Samin Jombloito, dan Samin Kasimpar. ${ }^{8}$

Hasil penelitian Siti Munfangati tentang masyarakat Samin di Desa Sumber, Kecamatan Kradenan, Kabupaten Blora, Jawa Tengah juga menyebutkan terdapat dua varian Samin yaitu Samin Lugu dan Samin Sangkak. Samin lugu adalah Samin "murni" bersikap sabar tidak pernah gentar sedikitpun, tidak pernah mendendam dan membalas dendam, segala sesuatu mereka hadapi dengan tenang. Mereka mempercayai hukum karma setiap orang akan menerima akibat perbuatannya. Samin Lugu juga disebut Jomblo-Ito artinya lahirnya bodoh dan tidak mengerti tetapi batin hatinya suci dan murni laksana emas. ${ }^{9}$

Samin Sangkak adalah Samin pemberani, bila mendapat lawan akan menangkis untuk melindungi diri sendiri. Mereka mudah menaruh curiga terhadap orang yang belum dikenal, suka membantah dengan alasan yang kurang masuk akal. Tetapi keduanya mempunyai perasaan dan budi yang halus. ${ }^{10}$

Dalam perkembangannya Samin di Desa Kemantren tumbuh subur, dikarenakan anak cucu Ki Samin sangat giat mempertahankan dan menyebarkannya. Tetapi sejak Indonesia merdeka dan sampai sekarang ini telah mengalami banyak perubahan dan pergeseran.

Bapak Syuhud, mantan Kepala Desa Kemantren, mengatakan bahwa penganut ajaran Samin pada periode kepemimpinannya di desa ini terdapat sekitar 73 Kepala Keluarga. Sedangkan menurut Bapak Sadiman, Kepala Desa sesudahnya, paham

8 RPA. Soerjanto Sastroatmodjo, Masyarakat Samin: Siapakah Mereka? Jogyakarta: Narasi, 2003), hal. 20.

9 www.id.wikipedia.org/Ajaran_Samin/accessed 20 Mei 2007.

10 www.id.wikipedia.org/Ajaran_Samin/accessed 20 Mei 2007. 
Samin dianut oleh hampir semua orang tua Dusun Tanduran meskipun anak-anak mereka ada yang tidak menganut Saminisme. ${ }^{11}$ Ajaran Samin menurut aparat desa yang lain seperti Bapak Amin (Bayan) di Tanduran ini juga sedikit demi sedikit juga ditinggalkan oleh penganutnya dikarenakan adanya persinggungan dan akulturasi kebudayaan dari dunia luar. ${ }^{12}$

Adapun keturunan Samin di Desa Kemantren yang pertama kali meninggalkan ajarannya yaitu Mbah Padi menantu dari Karto Kemis (cucu menantu Samin Surantiko). Beliau menuturkan: "...aku iki mantune Karto Kemis. Anake ki Samin Surantiko, aku iki sing duwe gaman dikik dewe, ning wis ora tak enggo, yen lake ijih tak lakoni ning yek anak turunku ben koyo wong okeb-okeh." (Saya ini anak mantunya Karto Kemis anak pertama Samin Surontiko, saya ini termasuk generasi pertama yang mengikuti ajaran ini tapi sudah saya tinggalkan kalau sebagai laku masih tapi untuk anak cucu saya biar seperti orang pada umumnya). ${ }^{13}$

Apa yang dilakukan Mbah Padi ini tentunya membawa implikasi terhadap perkembangan ajaran Samin sehingga banyak pula yang sedikit demi sedikit meninggalkan ajaran Samin. Sementara itu menurut aparat desa dan tokoh masyarakat pergeseran itu dikarenakan adanya persinggungan dan akultrasi kebudayaan dari dunia luar.

Meski demikian hingga saat ini masih banyak penduduk di desa ini yang masih mempertahankan adat dan tradisinya. Setidaknya ada 400 orang Samin di Dukuh Tanduran, sebagaimana yang disampaikan oleh Bapak Nyamu (sesepuh Samin). Beliau adalah cicit (generasi ke-empat) dari pendiri Samin. Generasi Samin dari awal hingga generasi ke empat: Ki Samin Surontiko, Surokidin, Saribin, dan Nyamu. ${ }^{14}$

\section{Kearifan Lokal Masyarakat Samin}

Kearifan lokal masyarakat Samin dapat disarikan dari ajaran-ajaran Ki Samin yang tersimpan dalam sanubari wong Samin. Ajaran-ajaran tersebut dipelihara dan dijalankan oleh masyarakat Samin. Masyarakat samin, dalam memegang teguh ajaranajarannya ini tidak berpegang pada kitab tertulis, melainkan ajaran tradisi lisan yang turun temurun. Ajaran-ajaran lisan tersebut sangat fasih diucapkan dan dijadikan falsafah oleh masyarakat Samin terutama bagi generasi tua mereka. Secara umum dalam tradisi lisan orang Samin ada ucapan-ucapan yang dianggap ajaran, antara lain:

\footnotetext{
11 Wawancara tanggal 9 Juli 2007.

12 Wawancara tanggal 10 Juli 2007.

13 Siti Kasiyati, Perkawinan Adat Masyarakat Samin..., hal. 35-36.

14 Wawancara tanggal 8 Juli 2007.
} 
1. Agama iku gaman, adam pangucape, man gaman lanang (Agama merupakan senjata hidup)

2. Aja drengki srei, tukar padu, dahpen kemeren, aja kutil jumput bedhog calong (Janganlah mengganggu orang, jangan suka bertengkar, jangan iri hati, jangan suka mengambil (mencuri) barang milik orang lain tanpa seijin pemiliknya)

3. Sabar lan trokal empun ngantos jrengkke srei, empun ngantos riyo sapada, empun nganti pek pinek kutil, jumput bedhog colong (Berbuatlah sabar dan (...) janganlah mengganggu orang, jangan takabbur pada semua orang, janganlah mengambil barang milik orang lain tanpa seijinnya. Jangankan mengambil barang, sedangkan menjumpai barang tercecer di jalan itupun dijauhi)

4. Wit jeng Nabi kulo lanang demele kulo rabi, tata jeneng we'dok pangeran (...) kukh dhemen janji buk nikah empun kulo lakoni (Sejak nabi adam pekerjaan saya (laki-laki) kawin, laki ini mengawini perempuan bernama (......) saya berjanji setia padanya, hidup bersama telah saya jalani)

5. Turun, pangaran, salin sandangan, sedulur wedhok, sedulur lanang (Turun istilah untuk anak, pangaran untuk nama orang, salin sandangan untuk orang yang sudah mati, sedulur berarti mereka yang telah diakui sebagai warga, sedulur lanang artinya saudara laki-laki, sedulur wedhok artinya saudara perempuan). ${ }^{15}$

\section{E. Perubahan dan Kesinambungan Kearifan Lokal Saminisme}

\section{Faktor dan Aktor Perubahan}

Masyarakat Samin bersinggungan langsung dengan budaya Islam, di samping dikarenakan mereka hidup ditengah-tengah masyarakat Islam, juga pada prinsipnya mereka mengaku beragama Islam walaupun belum menjalankan ajaran Islam. Bambang Pranowo sebagaimana yang dikutip oleh Agus Nurhadi menyebutnya sebagai "Islam dereng nglampahi." "Tidak tepat dan tidak simpati bila menyebut mereka yang belum menjalankan Islam disebut dengan Islam KTP atau Islam

15 Siti Kasiyati Perkawinan Adat Masyarakat Samin..., hal. 37

16 Agus Nurhadi, Runtubnya Dikotomi Santri-Abangan, (Semarang: Laporan Penelitian IAIN Walisongo, 1998/1999), hal. 43. 
nominal, karena menurut Pranowo masalah religiositas itu bersifat dinamis. Sebab dari mereka ini masih ada harapan dan kemungkinan untuk menjadi santri yang mengamalkan ajaran Islam dengan baik dan benar. Ajaran-ajaran Ki Samin sendiri banyak yang bernuansakan Islam; disamping menggunakan kosa kata Islam juga konsep-konsep Islam, khususnya dalam dunia tasawuf.

Apa yang menjadi identitas dan kearifan lokal masyarakat Samin lahir dari keyakinan mereka dan merupakan ajaran para leluhur mereka. Terdapat banyak poin-poin positif dari identitas dan kearifan lokal yang mereka miliki. Orang Samin tersebar di beberapa daerah di Jawa Tengah maupun Jawa Timur. Di Jawa Tengah meliputi daerah Kudus, Pati, dan Blora. Di Jawa Timur di Bojonegoro masih mengamalkan identitas dan kearifan lokal meeka. Menurut informasi dari Bapak Nyamu, orang Samin yang tinggal di Dusun Tanduran yang kurang lebih 400 orang juga masih menjaga identitas dan kearifan lokal mereka. Beliau mengatakan saat ini jumlah mereka mulai menyusut di beberapa daerah. Kecuali di Dusun Tanduran jumlah orang Samin masih relatif banyak.

Sudah menjadi kodrat dari sebuah ajaran terdapat aspek-aspek tertentu yang bisa dan harus mengalami perubahan (changeable), walaupun terdapat aspek-aspek tertentu yang tetap dipertahankan atau tidak dapat dirubah (unchangeable) dalam situasi dan kondisi yang sedang dan terus berkembang. Tidak ketinggalan pula identitas kesaminan walaupun dalam masalah kearifan lokal mereka tidak mengalami perubahan.

Identitas berpakaian yang paling tampak berubah. Karena dalam keseharian mereka menggunakan pakaian yang dipakai oleh kebanyakan orang luar mereka. Kalaupun menggunakan pakaian ala Saminisme itupun di acara-acara tertentu dan dipakai oleh para orang tua pada umumnya. Identitas dalam perkawinan - sikep rabi- yang menjadi pembeda utama mereka, juga mulai ditinggalkan khususnya bagi mereka yang menikah dengan pihak luar Samin atau yang intensitas keislamannya meningkat.

Faktor-faktor yang mendukung ke arah perubahan itu bisa eksternal dan internal, serta ada aktor di balik perubahan itu. Pada faktor eksternal terdiri atas: pertama, diseminasi teknologi dan informasi. Modernisasi, globalisasi, kemajuan teknologi dan transportasi telah mempengaruhi pola hidup dan cara pandang mereka tentang hidup dan cara melanjutkan kehidupan. Hal ini terlihat dari sikap informan keturunan Samin yang tidak lagi mengikuti ajaran Samin. Pengaruh budaya global ini dapat dilihat dihampir setiap rumah warga Samin telah ada TV, Radio, sepeda 
motor bahkan sebagian dari mereka ada yang mempunyai mobil, traktor dan alat pertanian modern. ${ }^{17}$ Kemajuan transportasi memudahkan terjadinya mobilisasi manusia dari satu tempat ke tempat lain. Begitu pula revolusi teknologi informasi membuat orang bisa mengikuti perkembangan dan meniru budaya orang lain.

Kedua, pendidikan. Dewasa ini, seiring meningkatnya taraf pendidikan penduduk masyarakat Samin, yang dulunya setingkat SD, sekarang sudah sampai SLTP, SLTA bahkan ada yang di Perguruan Tinggi menjadikan ajaran Samin banyak ditinggalkan keturunannya, khususnya dalam hal perkawinan. Sedang dalam falsafah hidup lainnya mereka masih melaksanakannya dan diikuti karena sesuai dengan adat dan ajaran Islam (bagi mereka yang kemudian beragama Islam). ${ }^{18}$

Masih menurut Bapak Sadiman, semakin meningkatnya taraf pendidikan masyarakat bahkan ada yang sampai perguruan tinggi mengubah pola pikir mereka dari statis menjadi dinamis. Hal senada juga diungkapkan Bapak Amin, Bapak Muji, Bapak Ahmad (Pjs Kepala Desa sekarang). ${ }^{19}$

Sementara faktor internal berupa pergulatan pemikiran dan perenungan dari anak cucu keturunan Samin sendiri yang mencoba mendialektikakan ajaran-ajaran yang dianut oleh nenek moyang mereka merupakan faktor internal yang ikut mendorong perubahan dalam masyarakat Samin. Melalui pendidikan dan persinggungan dengan komunitas lain menjadikan mereka berfikir dan merenung bahwa banyak ajaran kebaikan yang diajarkan oleh Ki Samin, akan tetapi benarkah Ajaran Samin identik dengan kumpul kebo, atau harus melakukan hubungan suami isteri sebelum menikah? Bukankah Ki Samin Surontiko seorang muslim? Karena itulah anak muda pada umumnya sudah menganut agama Islam meskipun dari falsafah hidupnya tidak meninggalkan pesan-pesan moyangnya (Saminisme). Hal ini dapat kita baca dari sikap Bapak Sadiman selaku Kepala Desa yang menjabat selama 8 tahun lalu sebagai keturunan Samin yang sudah beragama Islam tetapi juga tetap bangga dengan falsafah hidup yang diajarkan moyangnya.

\section{Aktor Perubahan: Struktural dan Kultural}

\section{a. Aparat Pemerintah Desa}

Sejak Indonesia merdeka, secara sistematis dan terus menerus selalu dilakukan pendekatan agar orang mau mengikuti tata cara berbangsa

17 Observasi di Desa Kemantren, 7-21 Juli 2007.

18 Wawancara dengan Bapak Sadiman dan Ibu Amin, keturunan Samin Muslim tanggal 1112 Juli 2007.

19 Wawancara di Desa Kemantren tanggal 15- 20 Juli 2007. 
Indonesia. Dengan cara sosialisasi bahwa yang memerintah negeri ini tidak lagi Belanda, maka saat ini mereka telah mempunyai kesadaran membayar pajak dan mengikuti Pemilu. Hal ini sebagaimana diutarakan oleh Bapak Sadiman, mantan Kepala Desa periode 1999-2007, Bapak Ahmad (Pjs Kepala Desa) serta Bapak Amin selaku Kepala Urusan Pembangunan Dukuh Tanduran.

Selain itu upaya juga dilakukan agar masyarakat Samin mau mengikuti tata cara perkawinan menurut Undang-undang Nomor 1 tahun 1974 tentang Perkawinan. Setidaknya mau mencatatkan perkawinan mereka. Kegiatan persuasif ini telah dilakukan oleh aparat Desa khususnya dimulai pada tahun 1992 oleh Bapak Syuhud selaku Kepala Desa ketika itu, yang kebetulan juga sebagai guru Agama Islam Sekolah Dasar di Dukuh Tanduran.

Usaha persuasif ini dilakukan umumnya dalam suasana nonformal yakni pada waktu acara 'adang akeh' (resepsi perkawinan) biasanya sesudah resepsi secara adat para aparat desa menyarankan secepatnya menikah di KUA, kegiatan gotong royang atau bersih desa, pertemuan-pertemuan RT, ibu-Ibu PKK, dan Posyandu. ${ }^{20}$

Sementara itu dikalangan generasi muda sosialisasinya melalui kegiatan Karang Taruna dan Pencak Silat Kera Sakti. Upaya ini juga terus dilakukan oleh Bapak Sadiman, selaku Kepala Desa periode tahun 1999-2007. ${ }^{21}$

\section{b. Tokoh Agama dan Tokoh Masyarakat}

Upaya "penyadaran" ini tidak hanya dilakukan oleh aparat desa dan PPN/ KUA tetapi juga oleh tokoh agama dan tokoh masyarakat. Sebagaimana disampaikan oleh Bapak Masyhadi selaku tokoh masyarakat dan tokoh agama di desa tersebut, menyatakan sebagai upaya menyebarkan agama Islam dikalangan Samin yakni dengan membangun Masjid di Dukuh Tanduran pada saat beliau menjabat. Upaya penyebaran ini tidak hanya dilakukan oleh aparat desa dan PPN tetapi juga oleh tokoh agama dan tokoh masyarakat (muslim). Secara "politis" Bapak Syuhud menunjuk Bapak Amin menjadi Kepala Urusan Pembangunan di Dusun Tanduran.

Sekarang ini di Dukuh Tanduran telah berdiri Masjid Assalam yang juga sudah memiliki asrama sebagai pondok pesantren. Penyebaran agama Islam di Tanduran tergolong pesat, yakni adanya pengajian Ibu-ibu setiap minggu Pon,

20 Wawancara dengan aparat Desa Kemantren tanggal 11-15 Juli 2007.

21 Wawancara tanggal 9 Juli 2007. 
dan tahlilan setiap seminggu sekali. Untuk Pengajian Ibu-ibu dipimpin langsung oleh Istri bapak Amin (selaku Kaur Pembangunan). Istri Bapak Amin ini merupakan perempuan Tanduran asli Samin yang dinikahi secara Islam.

\section{c. Masyarakat}

Komunitas Samin di Desa Kemantren bukanlah masyarakat yang tertutup, juga bukan masyarakat suku terasing. Mereka bebas bergaul dan berkomunikasi dengan siapa saja. Dari segi tampilan fisik tak ada yang bisa membedakan apakah dia Samin atau bukan. Oleh karena itulah masyarakat Samin ini tergolong cair dan dapat berdialog dengan masyarakat sekitar. Dari persinggungan budaya dan komunikasi sehari-hari dengan masyarakat lainya, maka sering kali terjadi akulturasi kebudayaan seperti perkawinan antar mereka. Samin tidak lagi hanya menjadi menantu orang Samin, tetapi banyak diantara mereka yang menjadi menantu masyarakat di luar komunitas Samin. Dengan demikian mereka yang menikah dengan tidak menggunakan tradisi dan ajaran Samin tidak lagi dianggap menjadi wong Samin.

Hal ini sebagaimana diungkapkan Bapak Sadiman, mantan Kepala Desa (beberapa bulan yang lalu baru saja non aktif untuk mengikuti pilihan Lurah Desa Kemantren), bahwa cara masyarakat Samin mempertahankan tradisi adalah menikahkan anak-anak mereka yang sesama Samin baik yang berada di Dukuh Tanduran ataupun di luar Tanduran. Sementara mereka yang menikah dengan orang luar (selain orang Samin) tidak lagi disebut orang Samin. Bapak Sadiman adalah keturunan Samin yag menikah dengan orang desa lain yang bukan penganut Samin. Demikian juga yang terjadi pada Bapak Muji (muslim) warga desa lain yang menikah dengan gadis keturunan Samin Dukuh Tanduran. Istrinya itu tidak disebut Samin lagi. ${ }^{22}$

\section{F. Upaya Memelihara Kesinambungan}

Walaupun pengaruh dan dakwah Islam sangat gencar di desa orang Samin, mereka tetap memegang teguh ajaran dari nenek moyang mereka, yang mereka sebut "Wali Adam" (Dam itu........li, yaitu kemaluan laki-laki). Masa lebih dari dua abad -terhitung sejak Ki Samin menyiarkan ajarannya sejak tahun 1890- bukanlah waktu yang cukup lama bagi sebuah ajaran atau sebuah isme untuk hidup dan

22 Wawancara tanggal 17 Juli 2007. 
berkembang. Namun selama lebih dua abad Saminisme telah membuktikan kekuatan ajarannya untuk membimbing pengikutnya. Apa yang membuat ajaran ini tetap laku dan menarik -minimal bagi orang Samin- serta dapat survive dalam jangka waktu lebih dua abad lamanya terlebih di tengah "gempuran" dakwah Islam dan kemajuan zaman?

Untuk "menghambat" laju "gempuran" dan perubahan yang bisa membuat mereka punah dan hanya tinggal cerita, orang Samin memiliki cara tersendiri di antaranya:

\section{Internalisasi Saminisme}

Mewariskan budaya Saminisme kepada anak keturunan mereka dilakukan secara langsung dengan cara menanamkan ajaran/internalisasi ajaran Samin. Sosialisasi kepada anak turun mereka bahwa ajaran yang mereka anut mempunyai nilai-nilai universal yang mengajarkan kebaikan, sehingga keturunan mereka tidak hanya hafal tentang ajaran-ajarannya tetapi juga memahami makna dan melaksanakannya dalam kehidupan dan perilaku sehari-hari.

\section{Limitasi Pendidikan}

Pendidikan dapat membuka cakrawala berfikir manusia seprimitif apapun mereka. Pendidikan juga bisa menjadi boomerang bagi pihak-pihak yang gigih mempertahankan sebuah tradisi. Upaya orang Samin melestarikan ajaran mereka yaitu dengan cara hanya menyekolahkan anaknya pada tingkatan rendah (SD). Hal ini dimaksudkan supaya anak mereka tidak terkontaminasi budaya dari luar. ${ }^{23}$

Limitasi pendidikan ini bagi orang Samin sudah lebih baik dibanding jika mengikuti ajaran Samin yang tidak boleh bersekolah. Dalam konsep ajaran Samin terdapat lima hal penting: [1] tidak bersekolah, [2] tidak memakai peci, tapi memakai "iket" yaitu semacam kain yang diikatkan di kepala mirip orang Jawa dahulu, [3] tidak berpoligami, [4] tidak memakai celana panjang, dan hanya pakai celana selutut, dan [5] tidak berdagang. ${ }^{24}$

\section{Kemandirian}

Masyarakat Samin memiliki lahan sawah dan ladang yang luas. Secara ekonomi mereka bisa memenuhi kebutuhan mereka sehari-hari tanpa bergantung kepada orang lain. Bagi mereka tidak ada yang dicari lagi bila pangan dan papan mereka

23 Wawacara dengan Bapak Nyamu dan Pujo tanggal 8-11 Juli 2007.

24 www.id.wikipedia.org/Ajaran_Samin/accessed 20 Mei 2007. 
sudah tercukupi. ${ }^{25}$ Tidak bergantung kepada orang lain membuat mereka lebih mandiri, terlebih dengan sawah dan ladang yang luas telah menyibukkan mereka untuk mengurus urusan lain. Ini juga yang membuat ajaran Samin dapat bertahan.

\section{Pernikahan Endogami}

Menjadi Samin diperoleh dari keturunan orang tua yang "murni" sama-sama Samin. Perbedaan asal usul salah satunya menyebabkan seseorang tidak dianggap menjadi Samin. Untuk menjaga kemurnian Saminisme perkawinan endogami (perkawinan sesama suku) menjadi prioritas bagi orang tua Samin. Perkawinan dengan orang luar Samin menjadi faktor utama penyiutan kuantitas dan otomatis berkurangnya aktor bagi pelestarian ajaran Saminisme.

\section{G. Penutup}

Lebih dari dua abad eksistensi Saminisme masih terjaga turun temurun dari generasi ke generasi. Walaupun dari segi kuantitas berkurang, namun masyarakat Samin sampai saat ini masih eksis ditengah-tengah kehidupan modern dan global. Identitas dan kearifan lokal mereka masih terpelihara. Identitas merupakan karakteristik yang membedakan satu kelompok dengan kelompok lainnya. Begitu pula dengan Saminisme. Identitas mencirikan ke "mereka" an 'wong Samin' yang meliputi identitas kesejarahan, pakaian, bahasa, tempat tinggal, perkawinan, dan dalam pertanian. Kearifan lokal merupakan khazanah batiniyah yang terpancarkan dalam level lahiriyah yang dimiliki oleh semua kelompok, begitu pula dengan 'wong Samin.' Kearifan mereka tampak dalam etika kepribadian, etika keselarasan sosial, dan etika terhadap alam.

Sebagai suatu entitas sosial yang dinamis, masyarakat Samin juga tidak bisa terhindar dari perubahan. Faktor ekternal dan internal terlibat dalam proses perubahan yang terjadi dalam masyarakat Samin. Faktor eksternal meliputi diseminasi teknologi dan informasi, serta pendidikan. Faktor internal lahir dari pergulatan batin beberapa orang Samin untuk melakukan refleksi atas ajaran Samin. Beberapa pelaku (aktor) perubahan juga terlibat baik secara struktural dan kultural. Secara struktural yaitu aparat pemerintah Desa, sementara secara kultural dilakukan oleh tokoh agama, dan masyarakat.

25 Wawancara dengan Bapak Nyamu dan Pujo tanggal 8-11 Juli 2007. 
Walaupun tidak bisa menghindar dari perubahan, tapi ada hal-hal tertentu yang tetap dijaga keberlangsungannya atau kesinambungannya. Kesinambungan ajaran Samin secara umum atau identitas dan kearifan lokal Saminisme secara khusus terjaga melalui internalisasi, limitasi pendidikan, self sufficiency, dan endogami.

\section{DAFTAR PUSTAKA}

Azizy, A. Qodri. 2003. Melawan Globalisasi. Yogyakarta: Pustaka Pelajar.

http://www.republika.co.id/koran_detail.asp?id=290290\&kat_id=3

http://id.wikipedia.org/wiki/Ajaran_Samin

Kasiyati, Siti. 1997. Perkawinan Adat Masyarakat Samin Dalam Konteks Pelaksanaan Undang-undang Perkawinan di Indonesia (UU Nomor 1 Tahun 1974): Studi Kasus di Desa Kemantren Kecamatan Kedungtuban, Kabupaten Blora. Surakarta: Skripsi STAIN Surakarta.

Koentjaraningrat. 1989. Pengantar Ilmu Antropologi. Jakarta: Aksara Baru.

Meuleman, Johan (ed). 2001. "Introduction" dalam Islam in the Era of Globalization: Muslim Attitudes Towards Modernity and Identity. Jakarta: INIS.

Nurhadi, Agus. 1998. Runtuhnya Dikotomi Santri-Abangan. Semarang: Laporan Penelitian IAIN Walisongo.

Sastroatmodjo, RPA. Soerjanto. 2003. Masyarakat Samin: Siapakah Mereka?. Yogyakarta: Narasi.

Subangun, Emmanuel. 1994. Dari Saminisme ke Posmodernisme. Yogyakarta: CRI Alocita. 